\title{
Phylogenetic analysis of intracellular bacteria of a harmful marine microalga, Heterocapsa circularisquama (Dinophyceae)
}

\author{
Teruya Maki ${ }^{1,3, *}$, Ikuo Yoshinaga ${ }^{2}$, Noriaki Katanozaka ${ }^{2}$, Ichiro Imai ${ }^{1}$ \\ ${ }^{1}$ Laboratory of Marine Environmental Microbiology, and ${ }^{2}$ Laboratory of Marine Microbiology, Division of Applied Biosciences, \\ Graduate School of Agriculture, Kyoto University, Kyoto 606-8502, Japan \\ ${ }^{3}$ Present address: Department of Chemistry and Chemical Engineering, Faculty of Engineering, Kanazawa University, \\ Kodatsuno 2-40-20, Ishikawa 920-8667, Kanazawa, Japan
}

\begin{abstract}
Heterocapsa circularisquama, a noxious marine dinoflagellate, has frequently caused red tides and killed cultured bivalves in western Japanese embayments. Observations by electron and epifluorescence microscopy revealed that many bacterial particles were detected inside the $H$. circularisquama cells. To elucidate the identity and origin of the intracellular bacteria associated with $H$. circularisquama, bacterial 16S ribosomal RNA genes (16S rDNA) were directly amplified by polymerase chain reaction from 5 clonal cultures of the algal strains that had been isolated from different localities. After cloning, randomly selected clones including the bacterial 16S rDNA fragments were sequenced. The results showed that intracellular bacterial populations consisted of only 2 ribotypes of bacteria, even though the algal strains were established from different localities. One ribotype (bac-G), which was dominant in the intracellular bacterial population, belonged to the gamma-proteobacteria group, and the other (bac-F) clustered with the Flexibacter-CytophagaBacteroides group. Both of these are novel species of endosymbiotic bacteria because of their unique 16S rDNA sequences. Furthermore, the populations of extracellularly associated bacteria were also composed of bac-G and bac-F, indicating that they originated from the intracellular bacteria. Fluorescence in situ hybridization targeting 16S rRNA indicated that bac-G appeared to localize on the algal nuclear surface, while bac-F was distributed in the cytoplasmic space of algal cells. These results strongly suggest that only a few species of specific bacteria reside and share their habitat in the $H$. circularisquama cells as endosymbionts.
\end{abstract}

KEY WORDS: Heterocapsa circularisquama · Dinoflagellate $\cdot$ Endosymbionts $\cdot$ Intracellular bacteria Gamma-proteobacteria subdivision · Flexibacter-Cytophaga-Bacteroides group · 16S rDNA · FISH

Resale or republication not permitted without written consent of the publisher

\section{INTRODUCTION}

The harmful dinoflagellate Heterocapsa circularisquama Horiguchi has frequently formed large-scale and long-term (more than $2 \mathrm{mo}$ ) red tides at several embayments in central and western Japan (Matsuyama et al. 1996). These red tides have severely damaged both natural and cultured bivalves, e.g. pearl oysters, shortnecked clams and oysters (Matsuyama et al. 1996).

Many species of microalgae generally get some benefits from co-existing bacteria through remineralized nutrients (Azam et al. 1983, Grossart 1999), vitamins (Haines \& Guillard 1974), and/or other unknown growth factors. Some microalgae also graze bacteria directly (mixotrophy) (Cole 1982, Caron et al. 1993, Keller et al. 1994). In many cases, co-existing bacteria benefit from microalgae through photosynthetic products (Bell et al. 1974, Jensen 1983). Electron microscopic observation revealed that most Heterocapsa circularisquama cells of culture strains possessed some bacteria-like particles (BLPs) intracellularly (Horiguchi 1995, Imai et al. 1999, Maki \& Imai 2001a). We previously 
reported that the intracellular BLPs grow or survive in H. circularisquama (Maki \& Imai 2001a). This implies the possibility that the intracellular BLPs are endosymbionts of $H$. circularisquama. Although there may be a special relationship between the intracellular bacteria and $H$. circularisquama, and the bacteria influence algal metabolism and reproduction, unfortunately it is not feasible to cultivate and identify the intracellular bacteria through conventional cultivation methods (Maki \& Imai 2001b).

Recently, microbial species compositions in a variety of natural samples have been analyzed through $16 \mathrm{~S}$ ribosomal RNA gene (16S rDNA) sequence analyses without cultivation (Amann et al. 1995). The cultureindependent analyses with molecular biological techniques have suggested that some novel bacteria, which have yet to be cultivated, exist in the ocean (Giovannoni et al. 1990, Fuhrman et al. 1993), hot springs (Ward et al. 1990), freshwater lakes (Shin et al. 1997), soil (Torsvik et al. 1990), and various other environments. In the case of symbiotic relationships, the bacterial communities associated with fish (Haygood \& Distel 1993, Aznar et al. 1994), insects (Ohkuma \& Kudo 1996, Fukatsu \& Nikoh 2000) and protozoa (Amann et al. 1991, Embley et al. 1992) have been analyzed through $16 \mathrm{~S}$ rDNA information, even though most of these bacteria were unculturable. Intracellular bacterial populations of the dinoflagellate Noctiluca scintillans were also investigated by the phylogenetic analysis (Seibold et al. 2001). Moreover, fluorescence in situ hybridization (FISH) analyses targeting ribosomes of certain microorganisms revealed that some marine organisms, such as marine bivalves (Distel \& Cavanaugh 1994, Sipe et al. 2000), tubeworms (Di Meo et al. 2000), shipworms (Distel et al. 1991) and an oligochaete worm (Dubilier et al. 2001), have various symbiotic bacteria in their tissues. With regard to unicellular organisms, endosymbiotic bacteria inside ciliate cells (Amann et al. 1991, Springer et al. 1992) or ectosymbiotic bacteria of anaerobic ciliates (Fenchel \& Ramsing 1992) were also detected using the FISH technique.

In this study, the 16S rDNA of bacteria associated with 5 different strains of Heterocapsa circularisquama, isolated from different localities in Japan, were analyzed to identify the bacteria without cultivation. Although the clonal cultures of $H$. circularisquama were established by thorough micropipette washing, the co-existing bacteria (intracellular and extracellular bacteria) were still observed under epifluorescence microscopy (Imai et al. 1999, Maki \& Imai 2001a,b). The 16S rDNA information newly obtained in this study suggested that 2 specific new species of bacteria occupied H. circularisquama cells. Moreover, to investigate the distribution of the bacteria inside the algal cells, we applied the FISH technique using fluorescently labeled nucleotide probes, specifically designed for the 16S rRNA of intracellular bacteria.

\section{MATERIALS AND METHODS}

Cultures of Heterocapsa circularisquama strains. The 5 clonal cultures of Heterocapsa circularisquama strains (HY9423, HU9433, HU9436, HA92-1 and HI9428) used in this study were kindly provided by Drs. T. Uchida and Y. Matsuyama at the National Research Institute of Fisheries and Environments of the Inland Sea. The cultures originated from seawater at 4 different localities in 1992 and 1994 (Fig. 1). Each algal culture was established by picking a single algal cell from a natural seawater sample and placing it into modified SWM-3 culture medium (Chen et al. 1969, Imai et al. 1996) using micropipettes; the cell was kept in the

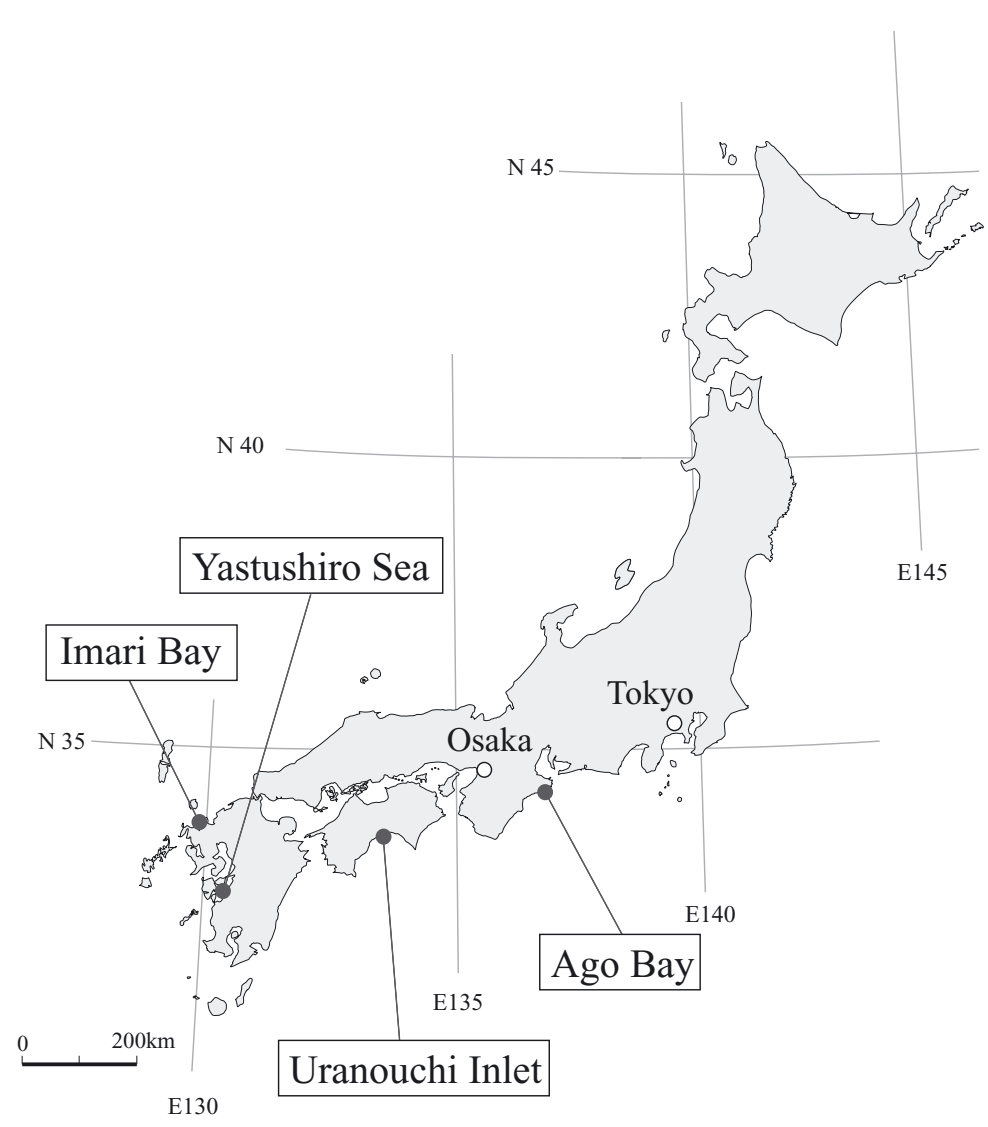

Fig. 1. Localities of sampling sites $(\bullet)$ from which the Heterocapsa circularisquama strains were obtained. Algal strains were isolated from: Yastushiro Sea (HY9423), Imari Bay (HI9428), Uranouchi Inlet (HU9433 and HU9436) in 1994 by Dr. T. Uchida, and from Ago Bay (HA92-1) in 1992 by Dr. Y. Matsuyama 
medium for $30 \mathrm{~s}$ and then transferred to a new medium, according to the pipette-washing protocol (Droop 1954, Hoshaw \& Rosowski 1973). The algal cell was repeatedly washed more than 6 times, and cultivated in the SWM-3 medium. Each (mono)clonal culture of $H$. circularisquama was started from a single cell. In general, the pipette-washing protocol eliminates (contaminated) bacteria that may be co-existing with the algal cells, and has been most effective for establishing axenic microalgal culture. However, $H$. circularisquama cultures have still included bacteria extracellularly and intracellularly. After isolation, all algal cultures were maintained in the modified SWM-3 culture medium, under a 14:10 h light:dark photo-cycle at a light intensity of $180 \mu \mathrm{mol}$ photon $\mathrm{m}^{-2} \mathrm{~s}^{-1}$ at a temperature of $22^{\circ} \mathrm{C}$.

Phylogenetic analysis of $16 \mathrm{~S}$ rDNA. Nucleotide sequences of 16S rDNA of the intracellular and extracellular bacteria associated with Heterocapsa circularisquama strains were determined. Five $H$. circularisquama strains were cultivated in modified SWM-3 medium (1 l) up to an algal cell density of $5 \times 10^{4}$ cells $\mathrm{ml}^{-1}$, and the algal cells containing intracellular bacteria were pelleted by centrifugation at $2600 \times g$ for 15 min, followed by washing twice with fresh SWM-3 saline. The supernatant was centrifuged again at $28000 \times g$ for $15 \mathrm{~min}$, and the extracellular bacteria were thus harvested. Both algal and extracellular bacterial cell pellets were stored at $-70^{\circ} \mathrm{C}$ until the following experiments.

The algal cell pellets containing intracellular bacteria were pulverized in liquid nitrogen with a ceramic blender. Grinding in liquid nitrogen minimized the degradation of bacterial DNA by algal nucleases. We did not perform any special steps to separate the intracellular bacteria from algal cell debris. Genomic DNAs of the intracellular and extracellular bacteria were extracted and purified using a DNA extraction kit (Sepa Gene, Sanko Junyaku).

The 16S rDNA fragments (ca. $1450 \mathrm{bp}$ ) of bacteria were amplified by polymerase chain reaction (PCR). Reaction mixtures (final volume, $100 \mu \mathrm{l}$ ) contained $200 \mu \mathrm{M}$ of dNTPs, 0.5 units of Ex Taq polymerase (Takara Bio), and $0.2 \mu \mathrm{M}$ each of oligonucleotide primers $6 \mathrm{~F}$ and 1492R (Table 1). These primers specifically bind to eubacterial 16S rDNA. Genomic DNA of bacteria was added at a final concentration of 1 to $10 \mathrm{ng}^{\mathrm{l}} \mathrm{l}^{-1}$. Thermal cycling was performed using a Program Temp Control System PC-700 (Astec) under the following conditions: denaturation at $95^{\circ} \mathrm{C}$ for $1 \mathrm{~min}$, annealing at $57^{\circ} \mathrm{C}$ for $2 \mathrm{~min}$, and extension at $72^{\circ} \mathrm{C}$ for $2 \mathrm{~min}$, for a total of 30 cycles. The PCR amplicons were separated by $1.5 \%$ agarose gel electrophoresis, and about 1450 bp of DNA bands (16S rDNA fragments) were excised and purified by phenol-chloroform extraction, chloroform extraction followed by ethanol precipitation. Finally, the DNA fragments were resuspended in $10 \mu \mathrm{l}$ of sterile distilled water.

The purified bacterial 16S rDNA fragments were cloned into Escherichia coli using a commercially prepared vector with a TA cloning kit (Invitrogen) according to the manufacturer's protocol. Transformation products were incubated for $18 \mathrm{~h}$ at $37^{\circ} \mathrm{C}$ on LB agar plate with $50 \mu \mathrm{g} \mathrm{ml}^{-1}$ of ampicillin and $40 \mathrm{\mu g} \mathrm{ml}^{-1}$ of Xgal. More than 25 white colonies per sample were picked up with sterile toothpicks, and more than 250 transformants were obtained (intracellular and extracellular bacteria of each of the 5 strains of Heterocapsa circularisquama). The recombinant plasmids were isolated from the individual transformants using a Plasmid Miniprep kit (Bio-Rad Laboratories).

Table 1. Oligonucleotides used as primers for amplification and as probes for FISH, and sequencing of 16S rDNA

\begin{tabular}{|c|c|c|c|}
\hline & Sequence $\left(5^{\prime}\right.$ to $\left.3^{\prime}\right)$ & Target organisms & Target site rRNA position \\
\hline \multicolumn{4}{|l|}{ Probe } \\
\hline Euca1195R & GGGCATCACAGACCTG & Eukaryote & 23S rRNA (1182-1195) \\
\hline Eub338R & GCTGCCTCCCGTAGGAGT & Eubacteria & 16S rRNA (323-338) \\
\hline Ark40R & TCCGGCAGGATCAACCGGAA & Archaebacteria & 16S rRNA $(21-40)$ \\
\hline G233R & GCTAATCTTTAAGCACGAGG & bac-G & 16S rRNA (214-233) \\
\hline F87R & GCAAGCACAACCTGTTACCC & bac-F & 16S rRNA $(68-87)$ \\
\hline \multicolumn{4}{|l|}{ Primer } \\
\hline M13(-40)F & GTTTTCCCAGTCACGA & & \\
\hline M13R & CAGGAAACAGCTATGAC & & \\
\hline $6 \mathrm{~F}$ & GRAGTTTGATCMTGGC & Eubacteria & 16S rRNA (6-24) \\
\hline $27 \mathrm{~F}$ & AGAGTTTGATCCTGGCTCAG & Eubacteria & 16S rRNA (8-27) \\
\hline $519 \mathrm{R}$ & GTATTACCGCGGCTGCTG & Eubacteria & 16S rRNA (519-536) \\
\hline $735 \mathrm{R}$ & GYCGCYTTCGCCACTGGTGT & Eubacteria & 16S rRNA (716-735) \\
\hline $926 \mathrm{R}$ & CCGTCAATTCMTTTGAGTT & Eubacteria & 16S rRNA (926-908) \\
\hline $\mathrm{S} 14 \mathrm{R}$ & CATTGTAGCACGTGTGTAG & Eubacteria & 16S rRNA (1241-1223) \\
\hline 1395R & GTACTTGGCCCGRGAAC & Eubacteria & 16S rRNA (1395-1379) \\
\hline $1492 \mathrm{R}$ & GGTTACCTTGTTACGACTT & Eubacteria & 16S rRNA (1510-1492) \\
\hline
\end{tabular}


Partial sequences (ca. $360 \mathrm{bp}$ ) of 16S rDNA clones were determined using a Dye Deoxy ${ }^{\mathrm{TM}}$ Terminator Cycle Sequencing Kit (Applied Biosystems) with the $27 \mathrm{~F}$ sequencing primer (Table 1) and DNA autosequencing system (Model 373A) according to the recommended protocol. The sequences determined were compared with the DDBJ (DNA Data Bank of Japan) database using the program Fasta Search (Altschul et al. 1990).

After alignment and comparing the partial nucleotide sequences of $16 \mathrm{~S}$ rDNA clones determined in this study, the clones were divided into ribotypes. Several representative clones of each ribotype were sequenced entirely (ca. $1450 \mathrm{bp}$ each). The primers for sequencing M13 (-40)F, M13R, 519R, 735R, 926R, S14R, 1395R are shown in Table 1.

All sequences were analyzed with Check-Chimera Version 2.7 (Ribosomal Database Project) to exclude the possibility of chimera production by PCR (RobisonCox et al. 1995). A phylogenetic tree including Heterocapsa circularisquama-associated bacteria was constructed according to the neighbor-joining algorithmic method (Saitou \& Nei 1987), using the ca. 1450 bp sequences of $16 \mathrm{~S}$ rDNA. Reference sequences in the phylogenetic tree were selected from the GenBank database (Table 2). Bootstrap analysis of up to 1000 replicates was carried out with the computer program Clustal W Version 1.7 (European Bioinformatics Institute) (Thompson et al. 1994).

Fluorescence in situ hybridization (FISH). To analyze the bacterial distribution, the intracellular bacteria of Heterocapsa circularisquama were stained and observed using the FISH technique with newly designed nucleotide probes (Table 1). The nucleotide probes targeting the intracellular bacteria were designed using the $16 \mathrm{~S}$ rDNA sequences. In addition, the probes Eub338R for eubacteria (Amann et al. 1990a) and Ark40R for archaebacteria (Giovannoni et al. 1988) were also used as a positive and a negative control, respectively (Table 1). The probe Euca1195R (Giovannoni et al. 1988) was used to detect eukaryotic ribosomal RNA in $H$. circularisquama cells. Algal cells of the $5 \mathrm{H}$. circularisquama strains were fixed with paraformardehyde solution (final concentration of $4 \%$ ) in phosphate-buffered saline (200 mM sodium phosphate buffer, $\mathrm{pH}$ 7.4) for $3 \mathrm{~h}$ at room temperature, and then fixed algal cells with the associated bacteria were bound on nuclepore filters $(0.2 \mu \mathrm{m}$ pore size). Each nuclepore filter was put into an Eppendorf tube and washed sequentially with 50, 80 and $100 \%$ ethanol for $1 \mathrm{~min}$. Then, $20 \mu \mathrm{l}$ of hybridization solution (30\% formamide, $0.9 \mathrm{M} \mathrm{NaCl}, 0.1 \%$ sodium dodecyl sulfate, $20 \mathrm{mM}$ Tris buffer, $\mathrm{pH}$ 7.2) was added to each sample on the nuclepore filter. Following preincubation at $37^{\circ} \mathrm{C}$ for $30 \mathrm{~min}, 9 \mu \mathrm{l}$ of hybridization solution contain-
Table 2. Sequence accession numbers (Acc. no.) for the $16 \mathrm{~S}$ rDNA clones from intracellular bacteria of Heterocapsa circularisquama and for the reference sequences used in hylogenetic analysis

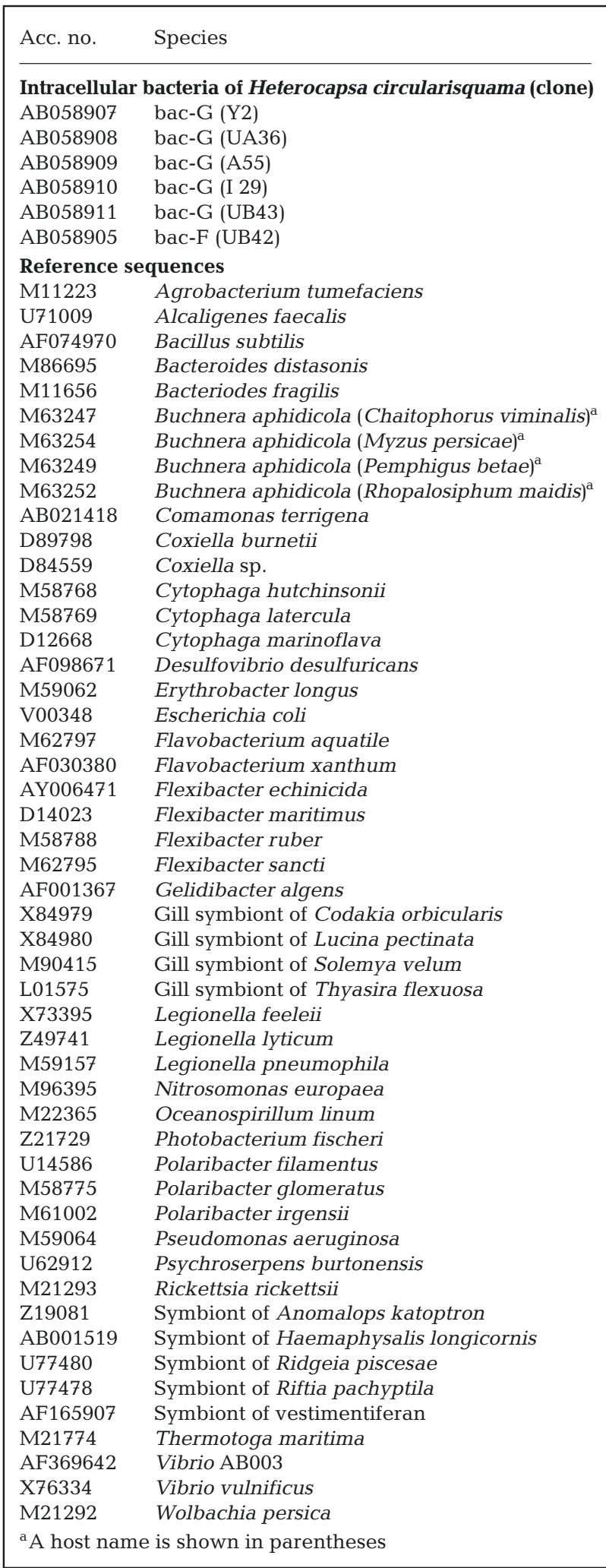


ing $2.5 \mu \mathrm{g}$ of fluorescence isothiocyanate (FITC)labeled probe was added. The algal cells were hybridized at $37^{\circ} \mathrm{C}$ for $6 \mathrm{~h}$ in a water bath and washed twice with 20 to $40 \mu \mathrm{l}$ of hybridization solution at $37^{\circ} \mathrm{C}$ for $20 \mathrm{~min}$.

After hybridization and washing, the nuclepore filter with the algal cells was placed on a filtering device and rinsed with distilled water. Subsequently, the filter was observed under an epifluorescence microscope (Nikon) equipped with the dichroic mirror system for FITC (excitation wavelength, 465 to $495 \mathrm{~nm}$; dichroic mirror, $505 \mathrm{~nm}$ ). Photomicrographs were taken with color reversal $400 \mathrm{~nm}$ film (Fujifilm). Exposure time was $0.5 \mathrm{~s}$ for epifluorescence micrographs.

\section{RESULTS}

\section{Comparison of $16 \mathrm{~S}$ rDNA clones}

16S rDNA fragments (ca. $1450 \mathrm{bp}$ ) of intracellular and extracellular bacteria co-existing with the 5 Heterocapsa circularisquama strains were amplified by PCR with primers targeting eubacterial 16S rDNA. The PCR amplicons were cloned into Escherichia coli, and a total of 293 clones including eubacterial 16S rDNA fragments was obtained. Partial sequences (ca. $360 \mathrm{bp}$ ) of the $16 \mathrm{~S}$ rDNA clones showed that the bacterial populations from the 5 different strains of $H$. circularisquama were divided into only 2 ribotypes. The pairwise sequence similarities among clones of each ribotype were high and ranged from 99.1 to $100 \%$, even when they were obtained from different $H$. circularisquama clones. All sequence variations of 16S rDNA clones obtained from intracellular (145 clones) and extracellular (148 clones) bacterial populations were aligned in Figs. $2 \& 3$. One major ribotype (bac-G; Fig. 2) is composed of 273 clones and is similar to Coxiella burnetii (average sequence similarity, $93.3 \%$ ), which belongs to the gamma-proteobacteria subdivision. The other minor ribotype (bac-F), which comprised the remaining 20 clones, was related to Flexibacter maritimus (average sequence similarity, $90.5 \%$ ) from the Flexibacter-Cytophaga-Bacteroides group (FCB-group) (Fig. 3). The ribotype bac-G was predominantly detected in all 5 strains of $H$. circularisquama (HY9423, HU9436, HA92-1, HI9428 and HU9433), whereas the ribotype bac-F was recovered from 3 strains only (HA92-1, HI9428 and HU9433; Table 3). As intracellular bacteria, bac-F was detected in only 1 algal strain (HU9433; Table 3).

To compare the extracellular bacterial populations with the intracellular bacterial populations, 148 clones of 16S rDNA amplicons were sequenced from culture supernatants of the 5 algal strains (see 'Materials and methods'). Their partial sequences demonstrated that most (131/148) of the clones from extracellular bacterial populations belonged to the ribotype bac-G, and pairwise similarities between intracellular and extracellular clones attained $99.0 \%$ (Fig. 2). The remaining 17 of the 148 clones belonged to the ribotype bac-F (>99.1\% similarity; Fig. 3). The ribotype bac-G clones were also obtained from all 5 algal strains in intracellular bacteria; however, the bac-F clones were detected from 3 strains in extracellular bacterial populations (HA92-1, HI9428 and HU9433), with ratios to the total clones being 3 (1/31), 10 (3/31) and 42\% (13/31), respectively (Table 3 ).

\section{Phylogenetic analysis}

The entire nucleotide sequences (ca. $1450 \mathrm{bp}$ ) of $16 \mathrm{~S}$ rDNA clones belonging to the ribotype bac-G (clone name: UB43) and the ribotype bac-F (clone name: UB42), which were originally amplified from the culture of Heterocapsa circularisquama strain HU9433, were determined. A wide-range phylogenetic tree that included UB43 and UB42 was constructed together with some 16S rRNA genes available from the DDBJ database (Fig. 4). The tree indicated that, as expected, UB43 (bac-G) belonged to the gamma-proteobacteria subdivision and UB42 (bac-F) belonged to the FCBgroup. Furthermore, 4 clones of 16S rDNA (Y2, UA36, A55 and I29, originating from the algal strains HY9423, HU9436, HA92-1 and HI9428, respectively), which all belonged to bac- $G$, were sequenced entirely as well as UB43. Although these 5 clones were originally derived from 5 different strains of $H$. circularisquama, their sequences were highly similar to each other and the pairwise similarities were more than 99.7\%. On a phylogenetic tree including the $516 \mathrm{~S}$ rDNA clones of bac-G and several known symbiotic or pathogenic gamma-proteobacteria (Fig. 5), the branch of bac-G

Table 3. Number of 16S rDNA sequence types retrieved from the intracellular bacteria and the extracellular bacteria in 5 Heterocapsa circularisquama strains. 16S rDNA clones belonging to the same ribotype, bac-G or bac-F, showed high degrees of similarity (more than 99.0\%) to each other

\begin{tabular}{|c|c|c|c|c|}
\hline \multirow[t]{2}{*}{ Strain } & \multicolumn{2}{|c|}{$\begin{array}{c}\text { Intracellular } \\
\text { bacterial population }\end{array}$} & \multicolumn{2}{|c|}{$\begin{array}{c}\text { Extracellular } \\
\text { bacterial population }\end{array}$} \\
\hline & bac-G & bac-F & bac-G & bac-F \\
\hline HY9423 & 26 & 0 & 26 & 0 \\
\hline HU9436 & 28 & 0 & 27 & 0 \\
\hline HA92-1 & 31 & 0 & 30 & 1 \\
\hline HI9428 & 31 & 0 & 30 & 3 \\
\hline HU9433 & 26 & 3 & 18 & 13 \\
\hline Total (clones) & 142 & 3 & 131 & 17 \\
\hline
\end{tabular}




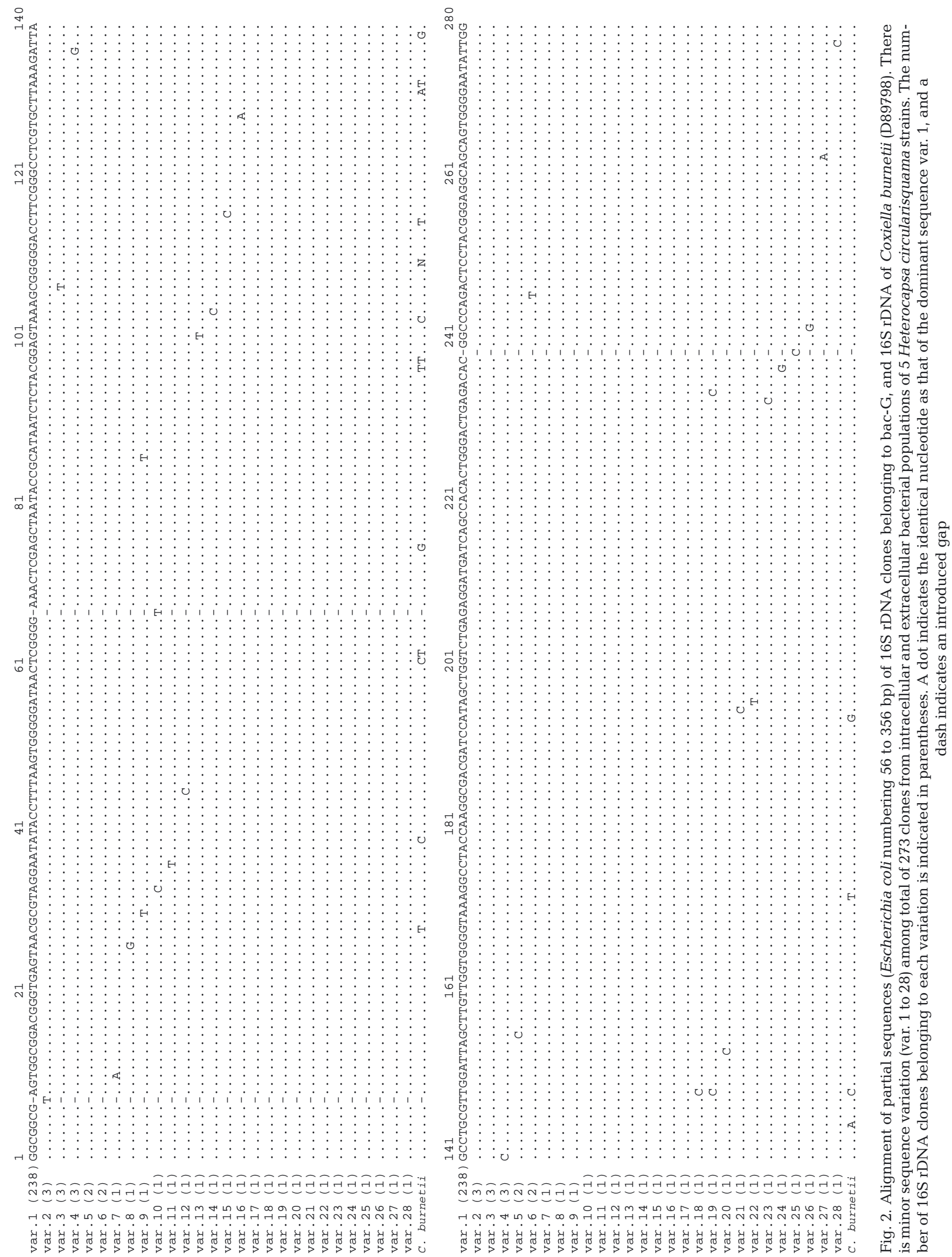




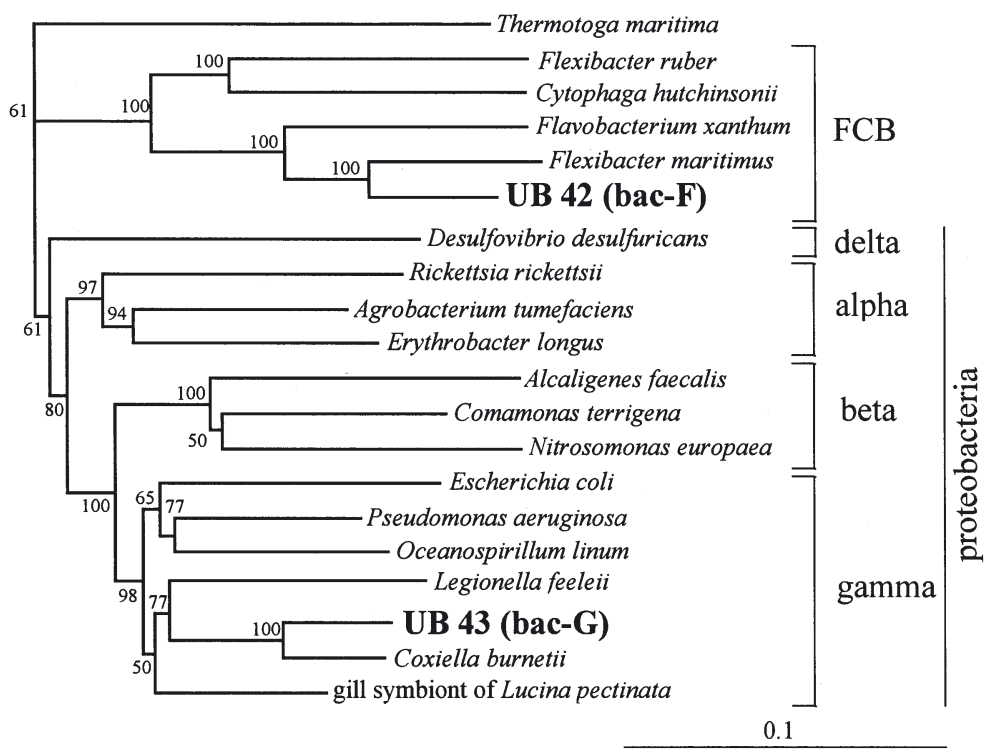

Fig. 4. A tree inferred from full-length nucleotide sequences of 16S rDNA (ca. $1450 \mathrm{bp}$ ) showing phylogenetic positions of 2 ribotypes (bac-F and bac-G) from intracellular bacteria of Heterocapsa circularisquama cells. Members of wellknown proteobacterial subdivisions (alpha, beta, gamma, delta) and FlexibacterCytophaga-Bacteroides (FCB) group in the DDBJ database are included. The tree was constructed according to the neighbor-joining algorithmic method (Saitou \& Nei 1987). Percentages of 1000 bootstrap simulations that supported each branch are indicated at each (neighbor-joining) node. Bootstrap values below $50 \%$ are not shown. The scale bar shows 10 nucleotide substitutions per

100 nucleotides. Sequence accession numbers are given in Table 2
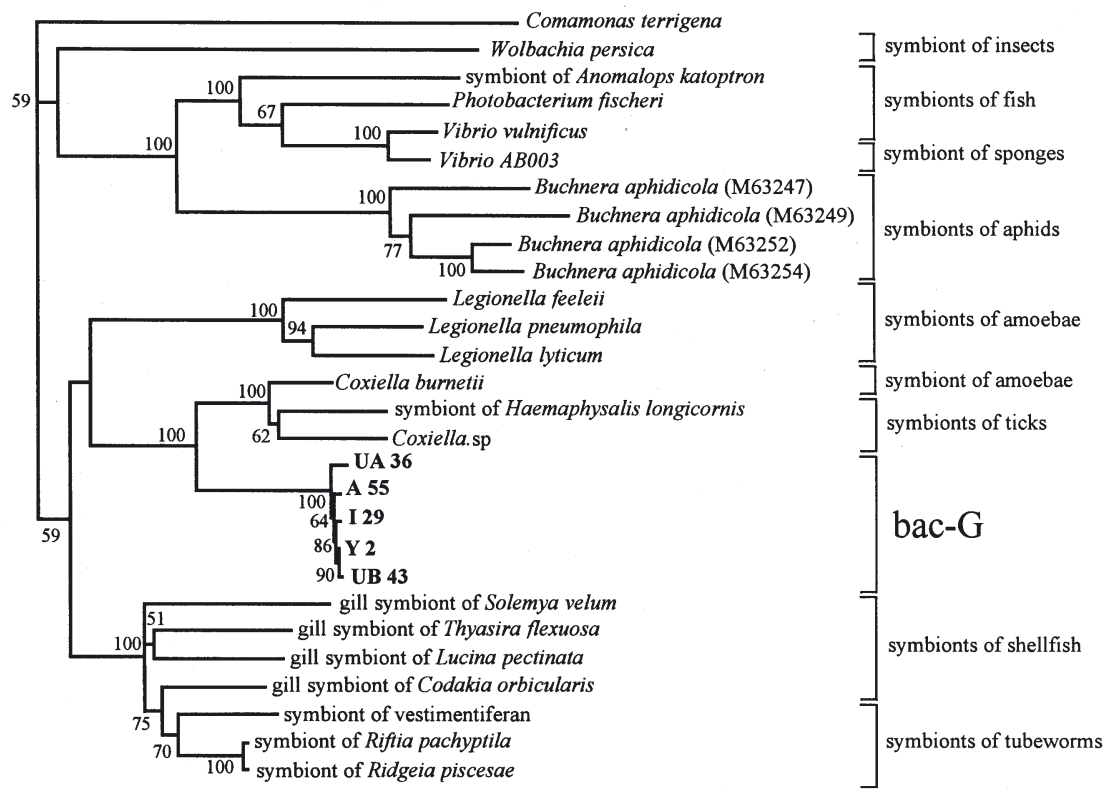

Fig. 5. Phylogenetic tree inferred from the full-length nucleotide sequences of $16 \mathrm{~S}$ rDNA (ca. $1450 \mathrm{bp}$ ) showing the relationship between 16S rDNA clones (Y2, UA36, A55, I29, and UB43) of the ribotype bac-G and several symbiotic gammaproteobacteria associated with eukaryotes. The tree construction and bootstrap simulation are referred to in Fig. 4 and 'Materials and methods'. Sequence accession numbers are given in Table 2 
clones related to a branch of Coxiella burnetii and 2 symbionts of ticks, but separated with $100 \%$ of bootstrap value. Another smallrange phylogenetic tree including UB42 (bac-F) and several members of the FCBgroup bac-F (Fig. 6) showed that the ribotype bac-F related to a branch of the genus Flexibacter, but is presumably a new species because of its low sequence similarities (90.5\% at most) with other members of Flexibacter.

\section{Whole-cell in situ hybridization of Heterocapsa circularisquama}

To investigate the distributions of bac-G-like and bac-F-like bacteria in Heterocapsa circularisquama cells, we designed FITC-labeled nucleotide probes targeting the ribosomal RNA of bac-G (probe G233R) and bac-F (probe F87R). These probes were complementary to a characteristic region of the retrieved 16S rRNA corresponding to positions 214 to 233 (G233R) and 68 to 87 (F87R) of Escherichia coli (Table 1). The hybridization conditions and specificities of the 2

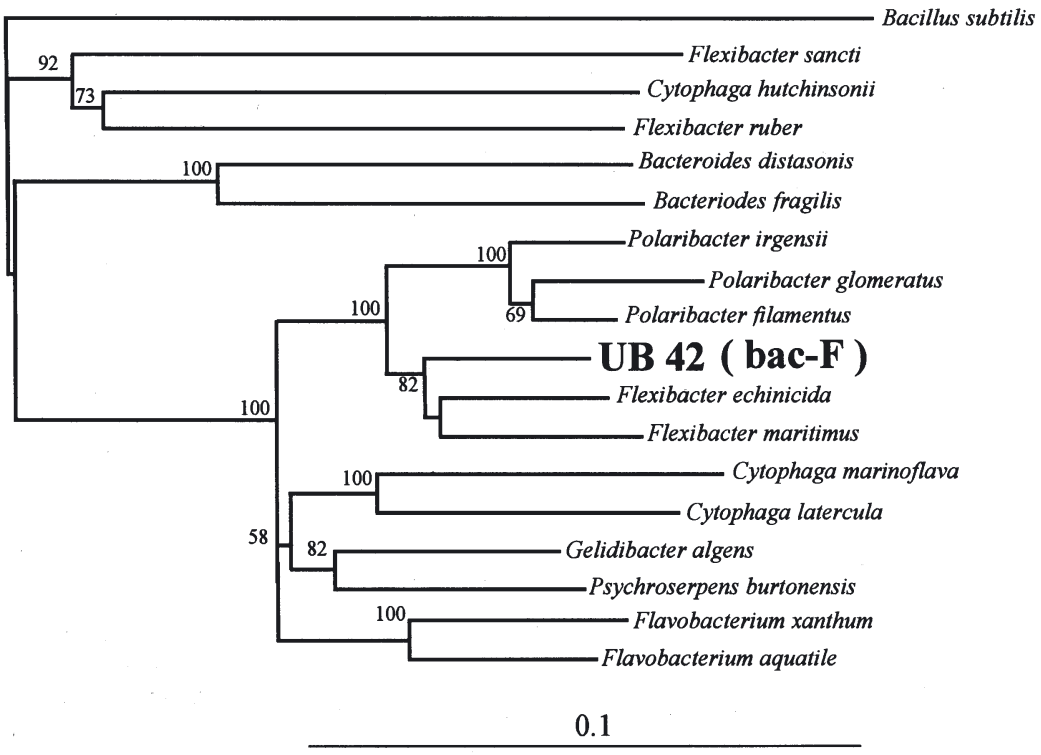

Fig. 6. Phylogenetic tree inferred from the full nucleotide sequences of 16S rDNA (ca. $1450 \mathrm{bp}$ ) showing the relationship between a clone of the ribotype bac-F and the members of the Flexibacter-CytophagaBacteroides (FCB) group in the DDBJ database. The tree construction and bootstrap simulation are referred to in Fig. 4 and 'Materials and methods'. Sequence accession numbers are given in Table 2 probes were determined preliminarily against some gamma-proteobacteria and GFC-group bacteria. In addition, a probe for eubacteria (Eub338R), a probe for archaebacteria (Ark40R), and a probe for eukaryotes (Euca1195R) were labeled with FITC. The position of algal nuclei were confirmed after DAPI (4',6-diamidino-2-phenylindole) staining and indicated with dashed lines in Fig. 7. Epifluorescence microscopy after whole-cell in situ hybridization of $H$. circularisquama cells revealed that the probe G233R for bac-G bound to the entire nuclear areas of all 5 algal strains analyzed (Fig. 7a). In contrast, the probe F87R targeting bac-F reacted with several small particles dispersed over the cytoplasm of the algal cells of $3 H$. circularisquama strains (HA92-1, HI9428 and HU9433; Fig. 7b). The signals by Eub338R (probe for eubacteria) as a positive control overlapped those by G233R and F87R, i.e. the nuclei of all $5 \mathrm{H}$. circularisquama strains and the cytoplasm of the 3 strains. Euca1195R (probe for eukaryotic ribosomes) labeled whole algal cells, and Ark40R (probe for archaebacteria) showed no signals.

The extracellular bacteria, which are composed of bac-G and/or bac-F by $16 \mathrm{~S}$ rDNA analysis, could not be detected by FISH using any of these probes in all 5 algal strain cultures. However, after the algal culture supernatants of HU9433 including extracellular bacteria were cultivated for $6 \mathrm{~h}$ with $10 \mathrm{mg} \mathrm{l}^{-1}$ of trypticase peptone, FISH signals of bacteria could be detected by using the F87R probe and the Eub338R probe.

\section{DISCUSSION}

Five clonal cultures of Heterocapsa circularisquama, which were isolated from different localities on the coast of western Japan, possessed BLPs intracellularly. It is significant to first identify the bacteria when investigating the relationships between intracellular bacteria and $H$. circularisquama. However, it was difficult to isolate and cultivate the bacteria independently from algal cultures, and therefore we analyzed the 16S rDNA sequences of bacteria without cultivation.

Microscopic observation by whole-cell in situ hybridization with the probes Ark40R for archaebacterial rRNA and Eub338R for eubacterial rRNA revealed that the intracellular bacteria in Heterocapsa circularisquama cells were derived from eubacteria, and not from archaebacteria (Fig. 7). This conclusion is supported by the fact that the PCR primer set for archaebacteria could not amplify any $16 \mathrm{~S}$ rRNA gene fragments from intracellular bacterial genomes. In contrast, eubacterial 16S rDNA was well amplified by PCR from the bulk DNA of intracellular bacteria in all 5 strains of $H$. circularisquama; it was cloned into Escherichia coli, and finally 26, 28, 31, 31 and 29 clones of 16S rDNA were obtained from algal strains HY9423, HI9428, HU9436, HA92-1 and HU9433, respectively. Based on the nucleotide sequence similarity, we divided a total of 145 clones of $16 \mathrm{~S}$ rDNA into groups (ribotypes). As a result, surprisingly, 145 clones of $16 \mathrm{~S}$ 
HY9432
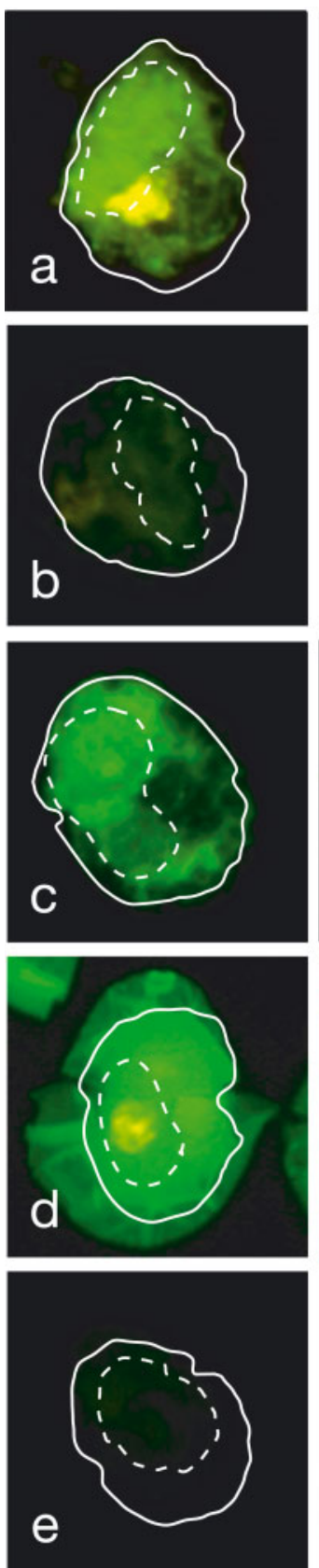

HU9436
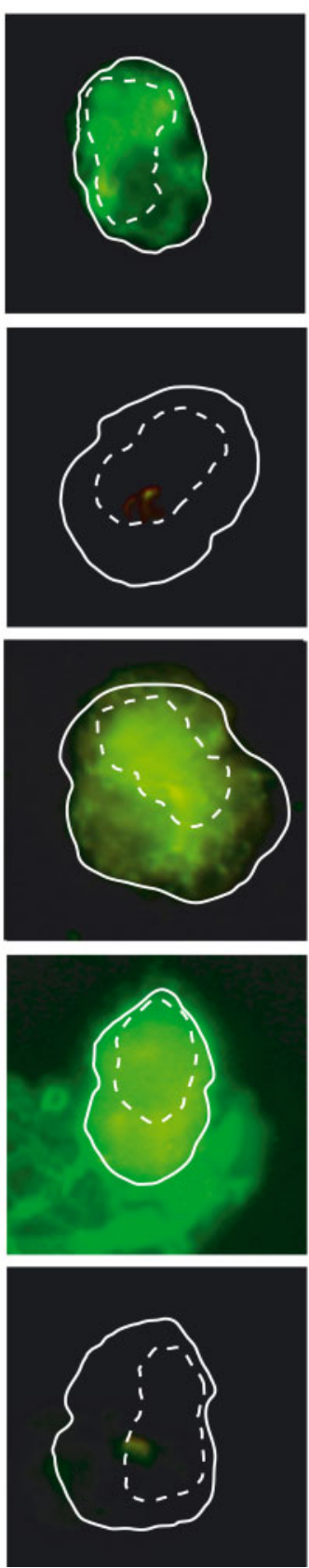

HA92-1
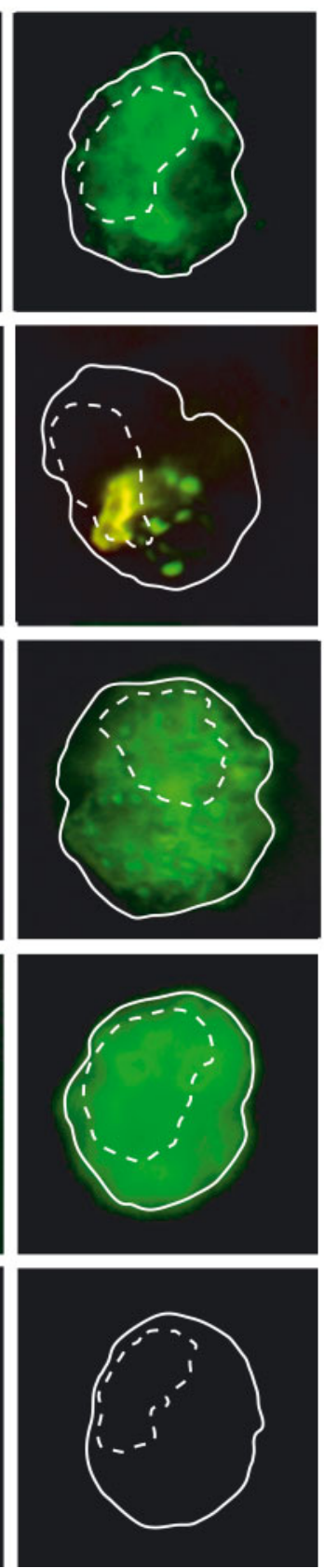

$\mathrm{H} 19428$
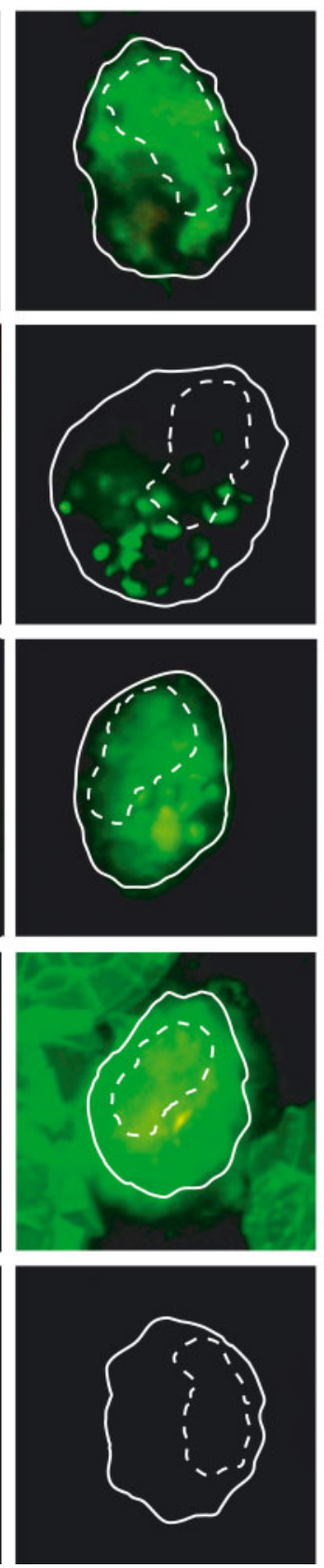

HU9433
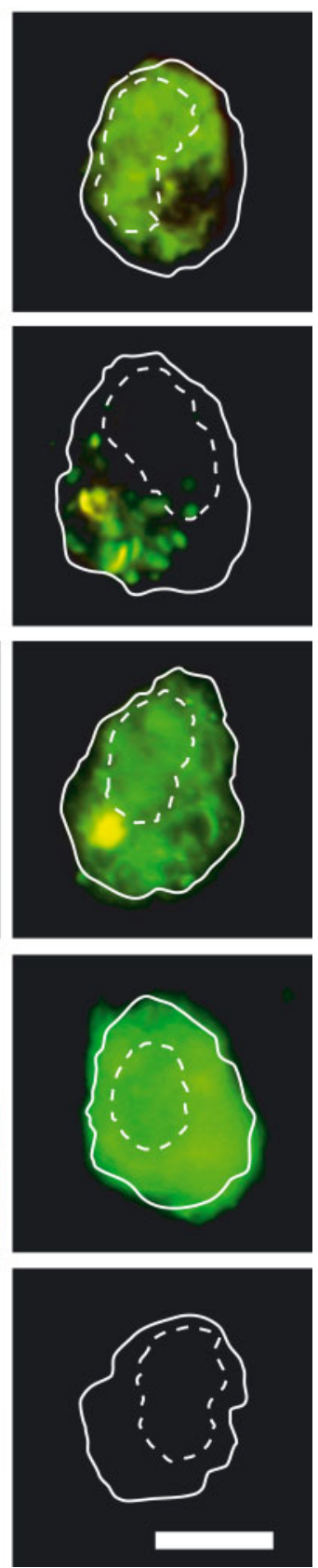

Fig. 7. Whole-cell in situ hybridization against bacteria-like particles in Heterocapsa circularisquama cells. Five algal strains (HY9423, HU9436, HA92-1, HI9428 and HU9433) are shown. Algal cells were hybridized and stained with 5 FITC-labeled probes: (a) G233R (probe for bac-G), (b) F87R (probe for bac-F), (c) Eub338R (probe for eubacteria), (d) Euca1195R (probe for eukaryotes), and (e) Ark40R (probe for archaebacteria), respectively. White lines in the micrographs show outline of the algal cells, and white dashed lines indicate outlines of nucleus observed after DAPI staining. All photomicrographs were taken at a magnification of $1000 \times($ scale bar $=10 \mu \mathrm{m})$

rDNA contained only 2 ribotypes (bac-G and bac-F), indicating that the intracellular bacterial populations are not so diverse. The ribotype bac-G was particularly dominant (142/145 clones) and was recovered from all 5 algal strains. In contrast, bac-F was obtained from the 3 clones only in the strain HU9433.
Only 2 eubacterial ribosome RNA genes were detected, nevertheless there are many kinds of bacteria around Heterocapsa circularisquama cells in natural environments. One plausible reason is that these 2 bacterial populations were artificially generated during isolation of microalgae. In this study, we 
used 5 strains of $H$. circularisquama which had been isolated from different bays far apart from each other (Fig. 1) collected on different dates by 2 different scientists. Furthermore, the thorough micropipettewashing protocol was used instead of antibiotics for the establishment of axenic algal culture. Therefore, it is inconceivable that the use of antibiotics or something related to the handling of microalgal culturing caused the poorly diverse bacterial populations in $H$. circularisquama cells. Furthermore, we detected the bacterial particles belonging to bac-G in the $H$. circularisquama cells which are isolated and maintained in other laboratories, using the FISH technique (data not shown).

Some scientists may point out that incorrect gene amplification during PCR could cause bias in bacterial species composition analysis. However, the PCR primers in this study for eubacterial 16S rDNA were widely used in various samples and we could amplify a variety of eubacterial 16S rDNA from lake water, seawater, coastal sands, and microalgal cultures. Consequently, we can conclude that 2 ribotypes of eubacteria (bac-G and bac-F) were generally associating with Heterocapsa circularisquama.

The populations of extracellular bacteria in cultures of Heterocapsa circularisquama were also investigated using the same protocol as that used for intracellular bacterial analysis. Sequence analysis of 148 clones of 16S rDNA amplicons from 5 different microalgal cultures indicated that the extracellular bacterial populations were also composed of the 2 ribotypes bac-G and bac-F. As expected, the $16 \mathrm{~S}$ rDNA clones of ribotype bac- $G$, which was dominant in the intracellular bacterial populations, was recovered more frequently than ribotype bac-F from all $5 \mathrm{H}$. circularisquama cultures. These observations indicate that the genetic population structures of the intracellular and extracellular bacteria were quite similar to each other.

Interestingly, $16 \mathrm{~S}$ rDNA clones of bac-F could be recovered from the extracellular bacteria of HA92-1 and HI9428 cultures, in which no 16S rDNA clones of bac-F were recovered from the intracellular bacteria. However, on whole-cell in situ hybridization targeting ribosomal RNA of bac- $F$, positive fluorescence was observed in algal cells of HA92-1 and HI9428, as well as of HU9433 (Fig. 7b). Genomic DNA of the intracellular bacteria may be difficult to extract from the algal cells, or some unknown interference such as algal cell components (Wintzingerode et al. 1997) might have inhibited PCR amplification of the 16S rDNA from bac-F in both algal strains (HA92-1 and HI9428). These results suggest that bac-F is an endosymbiotic bacterium that exists specifically in 3 strains of Heterocapsa circularisquama: HA92-1, HI9428 and HU9433.
We believe that the extracellular bacteria originated from the intracellular bacteria because of the following 2 reasons. First, to establish the axenic algal cultures, we washed the algal cells again with sterilized SWM-3 medium using micropipettes. This technique usually eliminates the extracellular bacteria. One week after the pipette-washing treatments, no extracellular bacteria existed in any of the algal cultures, while intracellular bacteria were observed by DAPI staining and epifluorescence microscopy. However, after several weeks' cultivation, the extracellular bacteria reappeared in the culture. This fact clearly indicates that the intracellular bacteria was released from algal cells (probably dead cells) and form the extracellular bacterial population as the algal cultivation proceeded. Second, it was difficult to detect extracellular bacteria by the whole-cell in situ hybridization technique. From our results, we deduce that the extracellular bacteria contained insufficient amounts of ribosome for FISH detection as the hybridization probes in this study targeted ribosomal RNA. This means that the extracellular bacteria are inactive, probably starved, outside algal cells (Kerkhof \& Ward 1993), a presumption which is supported by the fact that the bac-F type bacterial particles in the culture of HU9433 supernatant became detectable by FISH after the incubation with peptone addition.

Although a myriad of bacteria could possibly interact with the microalga in marine environments, only 2 types of bacteria were detected in this study. Most bacteria in natural environments which existed outside the algal cells could be eliminated by micropipettewashing during the isolation step of algal strains. However, the intracellular bacteria (bac-G and bac-F) remained associated with Heterocapsa circularisquama.

Several 16S rDNA fragments of ribotype bac-G from different Heterocapsa circularisquama strains were sequenced completely. The phylogenetic analysis suggests that the ribotype bac-G belongs to the gamma-proteobacteria subdivision (Figs. 5 \& 6). Some endosymbiotic bacteria belonging to the gammaproteobacteria have been previously identified in the tissues of various marine organisms such as finfish (Haygood \& Distel 1993, Aznar et al. 1994), shellfish (Distel \& Wood 1992, Distel \& Cavanaugh 1994, Sipe et al. 2000), tubeworms (Di Meo et al. 2000), and in the gut of aphids (Munson et al. 1991, Chen et al. 1999). The endosymbiotic bacterial group of amoebae, the genus Legionella, is also included in the gammaproteobacteria subdivision (Springer et al. 1992, Birtles et al. 1996). However, there are no symbiotic bacteria forming a single cluster with the bac-G clones except a kind of human pathogen (Coxiella burnetii) and endosymbionts of ticks (Noda et al. 1997). C. burnetii 
was reported to be a pathogen of mammals, causing Qfever (Baca \& Paretsky 1983), and it seems to survive in amoebae in the natural environment (La Scola \& Raoult 2001). Nevertheless, the sequence similarities between bac-G clones and some relatives in the databases were comparatively low $(\leq 94.1 \%)$. Accordingly, it is thought that the ribotype bac- $\mathrm{G}$ is a novel species/genus of endosymbiotic bacteria (Fig. 5).

There were few sequence variations among the bac-G clones. The pairwise sequence similarities among them were considerably high (at least 99.1\%) and some of the nucleotide transpositions in the alignment are most likely to be caused by unpredictable mistakes in PCR amplification. Therefore, it is suggested that the ribotype bac-G was composed of a single species, or of close relatives of bacterial species.

Based on the full-length 16S rDNA sequence, bac-F was also subjected to phylogenetic classification. Endosymbiont bac-F was shown to be related to a branch of Flexibacter maritimus and F. echinicida in the FCB-group (Fig. 6). However, the pairwise similarity values of bac-F for F. maritimus and F. echinicida were not significantly high (91.1 and 93.1\%, respectively). Therefore, bac-F was also considered to be a novel bacterium not cultured previously. Some bacterial strains of the FCB-group were reported as algalkilling (algicidal) bacteria against marine microalgae (Imai et al. 1993, 1998, Maeda et al. 1998, Yoshinaga et al. 1998, Kondo et al. 1999). Most of the algicidal FCB bacteria that kill certain marine microalgae attach directly, and thereafter lyse the microalgal cells (Imai et al. 1993). Although the present study did not provide any direct evidence to indicate that the bac-F type bacterial population kill and/or get organic nutrients from Heterocapsa circularisquama, it is probable that a wide variety of FCB-group bacteria live in close association with microalgae in marine environments.

Murray \& Stackebrandt (1995) reported the implementation of the provisional status Candidatus for incompletely described prokaryotes. We described the 2 intracellular bacteria bac-G and bac-F in this study by the sequence data. Accordingly, the 2 intracellular symbiotic bacteria should be categorized into the status Candidatus.

FITC-labeled DNA probes targeting 16S rRNA of bac-G (G233R probe) and bac-F (F87R probe) were prepared, and whole-cell in situ hybridization was performed against 5 strains of Heterocapsa circularisquama. Epifluorescence microscopy revealed that the fluorescent signals of the eubacteria-targeting probe (Eub338R) mostly covered the same areas of intracellular bacteria stained with bac-G or bac-F targeting probe (Fig. $7 \mathrm{a}-\mathrm{c}$ ). This observation might support our conclusion that the poor diversity of intracellular bacterial populations by $16 \mathrm{~S}$ rDNA-PCR analysis was not a result of artifact during PCR and cloning steps. The fluorescent signal of bac-G was observed above the nuclear area of $H$. circularisquama cells, while the signal of bac-F was distributed over the cytoplasm as several small particles (Fig. 7a,b). In a previous study (Maki \& Imai 2001a), the intracellular bacteria were not observed in the nuclear area of $H$. circularisquama under electron microscopy. Accordingly, bac-G may localize on the nuclear surface, while bac-F would exist throughout the cytoplasmic space. The microscopic observations also support the possibility that both species of endosymbiotic bacteria shared their habitats in algal cells.

Previously we reported that the intracellular bacteria of Heterocapsa circularisquama grow or survive dependently on the alga in different degrees from essential to optional (Maki \& Imai 2001a,b). Most intracellular bacteria need living alga for their growth and survival, except the intracellular bacteria of $H$. circularisquama strain HU9433 (Maki \& Imai 2001b). Only bac-F of strain HU9433 is culturable on the medium for heterotrophic bacteria, but those of strains HA92-1 and HI9428 are not (data not shown). There may possibly be some differences in the physiological characteristics of bac-F type bacteria associated with different strains of microalgae, in spite of the bacterial species being the same.

The genetic analysis in this study revealed that only 2 species of bacteria (bac-G and bac-F) dominantly occupy the intracellular bacterial populations of Heterocapsa circularisquama, although many species of bacteria surround $H$. circularisquama in natural environments. Accordingly, $H$. circularisquama would spontaneously maintain 2 specific bacteria, by supporting their growth and survival (Maki \& Imai 2001b). It is suggested that the relationship between $H$. circularisquama and 2 ribotypes of bacteria is considerably close and should be termed as endosymbiosis. The $H$. circularisquama cultures used in this study have been kept in the laboratory for more than 5 yr. Such prolonged cultivation might reduce the bacterial species within the algal cells to only 2 species. There is also the possibility that natural $H$. circularisquama has more than 2 bacterial species as intracellular bacteria. However, the 2 bacterial species can at least be regarded as common symbiotic bacteria for $H$. circularisquama around Japanese embayments. Further investigation on the intracellular and extracellular bacterial populations associated with $H$. circularisquama in natural environments is necessary. The FISH technique is a powerful tool for detecting specific microbial populations in seawater samples (Amann et al. 1990a,b, Rehnstam et al. 1993, Roller et al. 1994), and would also be useful for detecting the endosymbiotic bacteria of $H$. circularisquama in marine environments. 
Additionally, detailed mechanisms in the symbiotic interaction between bacteria and Heterocapsa circularisquama should be studied further because several scientists have pointed out that bacteria associated with the toxic dinoflagellate Alexandrium spp. may influence the production of paralytic shellfish toxin (Hold et al. 2001). Lewis et al. (2001) suggested that intracellular BLPs were observed in some species of Alexandrium by electron microscopy, and therefore it would be interesting to discover whether the intracellular bacteria of $H$. circularisquama influence bivalve mortality.

Acknowledgements. We are grateful to Professors H. Nakahara and A. Uchida of Kyoto University for their encouragement and helpful advice. We thank Drs. M. Yamaguchi, T. Uchida and Y. Matsuyama of the National Research Institute of Fisheries and Environments of the Inland Sea for supplying the strains of Heterocapsa circularisquama. This study was supported in part by a grant in aid for Scientific Research (No. 10660178) from the Ministry of Education, Science, and Culture of Japan.

\section{LITERATURE CITED}

Altschul SF, Gish W, Miller W, Myers EW, Lipman DJ (1990) Basic local alignment search tool. J Mol Biol 215:403-410

Amann RI, Binder BJ, Olson RJ, Chisholm SW, Deverelux R, Stahl DA (1990a) Combination of 16S rRNA-targeted oligonucleotide probes with flow cytometry for analyzing mixed microbial populations. Appl Environ Microbiol 56: 1919-1925

Amann, RI, Krumholz L, Stahl DA (1990b) Fluorescentoligonucleotide probing of whole cells for determinative, phylogenetic, and environmental studies in microbiology. J Bacteriol 172:762-770

Amann RI, Springer N, Ludwig W, Görtz HD, Schleifer KH (1991) Identification in situ and phylogeny of uncultured bacterial endosymbionts. Nature 351:161-164

Amann RI, Ludwing W, Schleifer KH (1995) Phylogenetic identification and in situ detection of individual microbial cells without cultivation. Microbiol Rev 59:143-169

Azam F, Fenchel T, Field JG, Gray JS, Meyer-Reil LA, Thingstad F (1983) The ecological role of water-column microbes in the sea. Mar Ecol Prog Ser 10:257-263

Aznar R, Ludwig W, Amann RI, Schleifer KH (1994) Sequence determination of rRNA genes of pathogenic Vibrio species and whole-cell identification of Vibrio vulnificus with rRNA-targeted oligonucleotide probes. Int J Syst Bacteriol 44:330-337

Baca OG, Paretsky D (1983) Q fever and Coxiella brunette: a model for host-parasite interactions. Microbiol Rev 47: 127-149

Bell WH, Lang JM, Mitchell R (1974) Selective stimulation of marine bacteria by algal extracellular products. Limnol Oceanogr 19:833-839

Birtles RJ, Rowbotham TJ, Raoult D, Harrison TG (1996) Phylogenetic diversity of intra-amoebal legionellae as revealed by $16 \mathrm{~S}$ rRNA gene sequence comparison. Microbiology 142:3525-3530

Caron DA, Sanders RW, Lim EL, Marrase C, Amaral LA, Whitney S, Aoki RB, Porter KG (1993) Light-dependent phagotrophy in the freshwater mixotrophic chrysophyte Dinobryon sylindricum. Microb Ecol 25:93-111

Chen LCM, Edelstein T, McLchlan J (1969) Bonnemaisonia hamihera harioit in nature and in culture. J Phycol 5: $211-220$

Chen X, Li S, Aksoy S (1999) Concordant evolution of a symbiont with its host insect species: molecular phylogeny of genus Glossina and its bacteriome-associated endosymbiont, Wigglesworthia glossinidia. J Mol Evol 48: $49-58$

Cole JJ (1982) Interactions between bacteria and algae in aquatic ecosystems. Annu Rev Ecol Syst 13:291-314

Di Meo CA, Wilbur AE, Holben WE, Feldman RA, Vrijenhoek RC, Cary SC (2000) Genetic variation among endosymbionts of widely distributed vestimentiferan tubeworms. Appl Environ Microbiol 66:651-658

Distel DL, Cavanaugh CM (1994) Independent phylogenetic origins of methanotrophic and chemoautotrophic bacterial endosymbioses in marine bivalves. J Bacteriol 176: 1932-1938

Distel DL, Wood AP (1992) Characterization of the gill symbiont of Thyasira flexuosa (Thyasiridae: Bivalvia) by use of polymerase chain reaction and 16S rRNA sequence analysis. J Bacteriol 174:6317-6320

Distel DL, DeLong EF, Waterbury JB (1991) Phylogenetic characterization and in situ localization of bacterial symbiont of shipworms (Teredinidae: Bivalvia) by using 16S rRNA sequence analysis and oligodeoxynucleotide probe hybridization. Appl Environ Microbiol 57:2376-2382

Droop MR (1954) A note on the isolation of small marine algae and flagellates for pure cultures. J Mar Biol Assoc UK 33: 511-514

Dubilier N, Mülders C, Ferdelman T, de Beer D and 8 others (2001) Endosymbiotic sulphate-reducing and sulphideoxidizing bacteria in an oligochaete worm. Nature 411 : 298-302

Embley TM, Finlay BJ, Thomas RH, Dyal PL (1992) The use of rRNA sequences and fluorescent probes to investigate the phylogenetic positions of the anaerobic ciliate Metopus palaeformis and its archaeobacterial endosymbiont. J Gen Microbiol 138:1479-1487

Fenchel T, Ramsing NB (1992) Identification of sulphatereducing ectosymbiotic bacteria from anaerobic ciliates using 16S rRNA binding oligonucleotide probes. Arch Microbiol 158:394-397

Fuhrman JA, McCallum K, Davis AA (1993) Phylogenetic diversity of subsurface marine microbial communities from the Atlantic and Pacific Ocean. Appl Environ Microbiol 59:1294-1302

Fukatsu T, Nikoh N (2000) Endosymbiotic microbiota of the bamboo pseudococcid Antonina crawii (Insecta, Homoptera). Appl Environ Microbiol 66:643-650

Giovannoni SJ, DeLong EF, Olsen GJ, Pace NR (1988) Phylogenetic group-specific oligodeoxinucleotide probes for identification of single microbial cells. J Bacteriol 170: $720-726$

Giovannoni SJ, Britschgi TB, Moyer CL, Field G (1990) Genetic diversity in Sargasso sea bacterioplankton. Nature 345:60-63

Grossart HP (1999) Interactions between marine bacteria and axenic diatoms (Cylindrotheca fusiformis, Nitzschia laevis, and Thalassiosira weissflogii) incubated under various conditions in the lab. Aquat Microb Ecol 19:1-11

Haines KC, Guillard RRL (1974) Growth of vitamin $\mathrm{B}_{12}$ requiring marine diatoms in mixed laboratory cultures with vitamin $\mathrm{B}_{12}$-producing marine bacteria. J Phycol 10: $245-252$ 
Haygood MG, Distel DL (1993) Bioluminescent symbionts of flashlight fishes and deep-sea anglerfishes form unique lineages related to the genus Vibrio. Nature 363:154-157

Hold GL, Smith EA, Birkbeck TH, Gallacher S (2001) Composition of paralytic shellfish toxin (PST) production by the dinoflagellates Alexandrium lusitanicum NEPCC 253 and Alexandrium tamarense NEPCC 407 in the presence and absence of bacteria. FEMS Microbiol Ecol 36:223-234

Horiguchi T (1995) Heterocapsa circularisquama sp. nov. (Peridiniales, Dinophyceae): a new marine dinoflagellate causing mass mortality of bivalves in Japan. Phycol Res 45:129-136

Hoshaw RW, Rosowski JR (1973) Methods for microscopic algae. In: Stein JR (ed) Handbook of phycological methods - culture methods and growth measurements. Cambridge University Press, Cambridge, p 53-68

Imai I, Ishida Y, Hata Y (1993) Killing of marine phytoplankton by a gliding bacterium Cytophaga sp., isolated from the coastal sea of Japan. Mar Biol 116:527-532

Imai I, Itakura S, Matsuyama Y, Yamaguchi M (1996) Selenium requirement for growth of a novel red tide flagellate Chattonella verruculosa (Raphidophyceae) in culture. Fish Sci 62:834-835

Imai I, Kim MC, Nagasaki K, Itakura S, Ishida Y (1998) Relationships between dynamics of red tide-causing raphidophycean flagellates and algicidal micro-organisms in the coastal sea of Japan. Phycol Res 46:139-146

Imai I, Nakagiri S, Maki T (1999) Relationship between the harmful dinoflagellate Heterocapsa circularisquama and marine bacteria. Bull Plankton Soc Jpn 46:172-177

Jensen LM (1983) Phytoplankton release of extracellular organic carbon, molecular weight composition, and bacterial assimilation. Mar Ecol Prog Ser 11:39-48

Keller KD, Shapiro LP, Haugen EM, Cucci TL, Sherr EB (1994) Phagotrophy of fluorescently labeled bacteria by an oceanic phytoplankter. Microb Ecol 28:39-52

Kerkhof L, Ward BB (1993) Comparison of nucleic acid hybridization and fluorometry for measurement of relationship between RNA/DNA ratio and growth rate in a marine bacterium. Appl Environ Microbiol 59:1303-1309

Kondo R, Imai I, Fukami K, Minami A, Hiroishi S (1999) Phylogenetic analysis of algicidal bacteria (family Flavobacteriaceae) and selective detection by PCR using a specific primer set. Fish Sci 65:432-435

La Scola B, Raoult D (2001) Survival of Coxiella burnetii within free-living amoeba Acanthamoeba castellanii. Clin Microbiol Infect 7:75-79

Lewis J, Kennaway G, Franca S, Alverca E (2001) Bacterium-dinoflagellate interactions: investigative microscopy of Alexandrium spp. (Gonyaulacales, Dinophyceae). Phycologia 40:280-285

Maeda T, Murakami M, Ohsugi S, Furushita M, Mitsutani A, Shiba T (1998) Perspectives of the development of 16A rDNA probe specific for algicidal and/or algal-lytic gliding bacteria. Fish Sci 64:861-865

Maki T, Imai I (2001a) Relationships between intracellular bacteria and the bivalve killer dinoflagellate Heterocapsa circularisquama (Dinophyceae). Fish Sci 67:794-803

Maki T, Imai I (2001b) Effects of harmful dinoflagellate Heterocapsa circularisquama cells on the growth of intracellular bacteria. Microb Environ 16:234-239

Matsuyama Y, Uchida T, Nagai K, Ishimura M, Nishimura A, Yamaguchi M, Honjo T (1996) Biological and environmental aspects of noxious dinoflagellate red tides by Heterocapsa circularisquama in the west Japan. In: Yasumoto T, Oshima Y, Fukuyo Y (eds) Harmful and toxic algal blooms.
Intergovernmental Oceanographic Commission of UNESCO, Sendai, p 247-250

Munson MA, Baumann P, Clark MA, Baumann L, Moran NA, Voegtlin DJ, Campbell BC (1991) Evidence for the establishment of Aphid-eubacterium endosymbiosis in an ancestor of four Aphid families. J Bacteriol 173: 6321-6324

Murray RG, Stackebrandt E (1995) Taxonomic implementation of the provisional status Candidatus for incompletely described procaryotes. Int J Syst Bacteriol 45:186-187

Noda H, Munderloh UG, Kurtti TJ (1997) Endosymbionts of ticks and their relationship to Wolbachia spp. and tickborne pathogens of humans and animals. Appl Environ Microbiol 63:3926-3932

Ohkuma M, Kudo T (1996) Phylogenetic diversity of the intestinal bacterial community in the termite Reticulitermes speratus. Appl Environ Microbiol 62:461-468

Rehnstam AS, Backman S, Smith DC, Azam F, Hagström ^ (1993) Blooms of sequence-specific culturable bacteria in the sea. FEMS Microbiol Ecol 102:161-166

Robison-Cox JF, Bateson MM, Ward DM (1995) Evaluation of nearest-neighbor methods for detection of chimeric smallsubunit rRNA sequences. Appl Environ Microbiol 61: $1240-1245$

Roller C, Wagner M, Amann R, Ludwig W, Schleifer KH (1994) In situ probing of Gram-positive bacteria with high DNA $\mathrm{G}+\mathrm{C}$ content using 23S rRNA-targeted oligonucleotides. Microbiology 140:2849-2858

Saitou N, Nei M (1987) The neighbor-joining method: a new method for reconstructing phylogenetic trees. Mol Biol Evol 4:406-425

Seibold A, Wichels A, Schutt C (2001) Diversity of endocytic bacteria in the dinoflagellate Noctiluca scintillans. Aquat Microb Ecol 25:229-235

Shin MS, Yoshinaga I, Katanozaka N, Uchida A, Ishida Y (1997) Phylogenetic analysis by 16S rRNA gene sequencing of obligate oligotrophs isolated from the northern basin of Lake Biwa (mesotrophic lake). Microb Environ 12: $27-36$

Sipe AR, Wilbur AE, Cary SC (2000) Bacterial symbiotic transmission in the wood-boring shipworm Bankia setacea (Bivalvia: Teredinidae). Appl Environ Microbiol 66: 1685-1691

Springer N, Ludwig W, Drozanski W, Amann R, Schleifer KH (1992) The phylogenetic status of Sarcobium lkyticum, an obligate intracellular bacterial parasite of small amoebae. FEMS Microbiol Lett 96:199-202

Thompson JD, Higgins DG, Gibson TJ (1994) CLUSTAL W: improving the sensitivity of progressive multiple sequence alignment through sequence weighting, position-specific gap penalties and weight matrix choice. Nucleic Acids Res 22:4673-4680

Torsvik V, Goksoyr J, Daae FL (1990) High diversity in DNA of soil bacteria. Appl Environ Microbiol 56:782-787

Ward DM, Weller R, Bateson MM (1990) 16S rRNA sequences reveal numerous uncultured microorganisms in a natural community. Nature 345:63-65

Wintzingerode FV, Gobel UB, Stackebrant E (1997) Determination of microbial diversity in environmental samples: pitfalls of PCR-based rRNA analysis. FEMS Microbiol Rev 21:213-229

Yoshinaga I, Kimu MC, Katanozaka N, Imai I, Uchida A, Ishida Y (1998) Population structure of algicidal marine bacteria targeting the red tide forming alga Heterosigma akashiwo (Raphidophyceae), determined by restriction fragment length polymorphism analysis of the bacterial 16S ribosomal RNA genes. Mar Ecol Prog Ser 170:33-44 